\title{
Magdalena Dąbrowska*
}

Uniwersytet Warszawski

\section{PUBLICZNOPRAWNY MODEL OCHRONY KONKURENCJI W POLSCE}

\section{Streszczenie}

Celem artykułu jest opis przyjmowanych w Polsce rozwiązań w zakresie ochrony konkurencji w ujęciu historycznym. Artykuł prezentuje ewolucję modelu publicznoprawnej ochrony konkurencji przeprowadzoną na podstawie analizy literatury przedmiotu i dokumentów źródłowych. Z wykorzystaniem metody deskryptywnej opisuje pozycję ustrojową organu antymonopolowego w obowiązującym obecnie modelu, jak również pokrótce niektóre jego kompetencje.

Słowa kluczowe: model ochrony konkurencji, publicznoprawna ochrona konkurencji, organy antymonopolowe w krajach UE

\section{Wprowadzenie}

Przyjęty system ochrony konkurencji w Polsce jest przede wszystkim skutkiem procesu dostosowywania prawa polskiego do wymogów unijnych (Kabacińska, 2012), stąd obowiązujące w Polsce prawo ochrony konkurencji „składa się z dwóch podsystemów prawa: unijnego i krajowego" (Kabacińska, 2012, s. 2). Obecnie mówi się o zjawisku „konwergencji systemów ochrony konkurencji” (Krasnodębska-Tomkiel, 2015, s. 20) w UE, zwłaszcza w zakresie przeciwdziałania praktykom ogra-

* E-mail: magdalenadabrowska@onet.com.pl. 
niczającym konkurencję. Proces „przejmowania” przez krajowe organy ochrony konkurencji wzorca unijnego ma charakter dynamiczny, zaś jego przejawem jest wprowadzenie choćby takich rozwiązań, jak polityka łagodzenia kar (leniency) czy środki zaradcze (Krasnodębska-Tomkiel, 2015, s. 20 i nast.). Jednak rola organów ochrony konkurencji (antymonopolowych) w Polsce nie sprowadza się wyłącznie do zwalczania praktyk antykonkurencyjnych oraz naruszających prawa konsumentów, prewencyjnej kontroli procesów koncentracyjnych oraz sprawowania nadzoru nad przyznawaniem pomocy publicznej. Organ ten bowiem aktywnie współtworzy prokonkurencyjną politykę państwa (Ustawa z dnia 16 lutego 2007, art. 31, ust. 4).

Celem artykułu jest opis ewolucji modelu publicznoprawnej ochrony konkurencji w Polsce. Analiza literatury przedmiotu i dokumentów źródłowych pozwoliła na ukazanie zmian w podejściu państwa do ochrony konkurencji (w ujęciu historycznym). Wynikiem przeprowadzonych analiz jest krótka charakterystyka pozycji ustrojowej oraz kompetencji organu antymonopolowego po akcesji Polski do Unii Europejskiej.

\section{Pojęcie konkurencji}

Choć obecnie zjawisko konkurencji uznawane jest za „kanon gospodarki rynkowej” (Kosikowski, 2010, s. 316), pojęcie „konkurencji” nie zostało dotychczas normatywnie zdefiniowane. Jak wskazuje F.J. Säcker, „konkurencja jako instrument koordynacji i kontroli zachowań przedsiębiorczych pełni (...) rolę gwaranta wolności” (2010, s. 6). Wolna konkurencja to „otwarty dostęp do rynku na równych prawach dla wszystkich przedsiębiorców" (Gronowski, Wojtaszek-Mik, 1998, s. XV), który wymaga respektowania szeregu swobód gospodarczych (Powałowski, Koroluk, Mering, 2004, s. 16). Wolność konkurowania, w tym wolność działalności gospodarczej, nie ma jednak wymiaru absolutnego. Mimo ochrony przyznanej swobodzie prowadzenia działalności gospodarczej w ustawie zasadniczej (Konstytucja RP z dnia 2 kwietnia 1997, art. 20), to państwo władne jest do określania warunków korzystania z niej (Konstytucja, art. 22). Rolą władz publicznych jest również podejmowanie działań chroniących konsumentów (Konstytucja, art. 76), co „wiązać należy z obowiązkiem określenia standardów relacji konkurencyjnych (...)" (Powałowski i in., 2004, s. 251). Jednym z takich standardów jest ogólny nakaz nienaruszania równowagi rynkowej i mechanizmu konkurencyjnego. 
Już na tle ustawy z 1990 r. o przeciwdziałaniu praktykom monopolistycznym (j.t. Dz. U. z 1999 r. nr 52, poz. 547) wyrażono pogląd, że prawo antymonopolowe znajduje zastosowanie, gdy w następstwie zabronionych praktyk naruszony zostaje interes publicznoprawny, czyli w sytuacji, w której skutek nielegalnych działań dotyka szerszego kręgu uczestników obrotu (Podrecki, 1994, s. 21). Również przepisy obowiązującej ustawy objęły ochroną ,,interesy przedsiębiorców i konsumentów, które nie mają wymiaru indywidualnego (prywatnego)" (Bernatt, Jurkowska-Gomułka, Skoczny, 2014, s. 4). Nie każde naruszenie prawa w stosunkach cywilnoprawnych daje się automatycznie zakwalifikować jako podlegające postępowaniu z zakresu przeciwdziałania praktykom antykonkurencyjnym (Podrecki, 1994, s. 21; Sieradzka, 2015, s. 223; Błachucki, 2012, s. 46). Niemniej zachowania rynkowe uczestników rynku (przedsiębiorców) zawsze będą mogły podlegać ocenie przez pryzmat celów wyznaczonych w ustawie antymonopolowej, w tym pod kątem wpływu na mechanizmy konkurencyjne. Ochrona konkurencji w Polsce przebiega bowiem dwutorowo: $\mathrm{z}$ jednej strony $-\mathrm{w}$ interesie zbiorowym - chroni się mechanizm konkurencyjny na rynku, z drugiej zaś - w ramach tzw. modelu prywatnoprawnego - ochrona konkurencji realizuje się w postępowaniu przed sądem powszechnym (o wzajemnej relacji między kontrolą antymonopolową a cywilną więcej zob. m.in. Lewandowski, 2012, s. 32 i nast.; model prywatnoprawny szerzej m.in. Sieradzka, 2012). Dwutorowość systemu nie powinna dziwić, skoro prawodawstwo umożliwiające publicznoprawną ingerencję państwa na rynku pojawiło się dopiero w późniejszej fazie rozwoju polityki prokonkurencyjnej. Polityka ta na świecie także rozwijała się dwupłaszczyznowo: z jednej strony w kierunku rządowej regulacji rynków i konkurencji, z drugiej zaś poprzez ograniczanie i przeciwdziałanie procesom monopolizacji rynku (Zelek, 1999, s. 5).

\section{Ewolucja polskiego systemu ochrony konkurencji}

Początki systemu ochrony konkurencji w Polsce można wywieść jeszcze z okresu międzywojennego, kiedy to pojawiły się pierwsze regulacje o charakterze skodyfikowanym (o genezie tej np. Miąsik, 2013, s. 35 i nast.). Ochrona ta realizowana była zarówno przez zwalczanie nieuczciwej rywalizacji na rynku, jak i przez regulację karteli. W 1926 r. przyjęto ustawę o zwalczaniu nieuczciwej konkurencji (j.t. Dz. U. z 1930 r. nr 56, poz. 467), która stała się podstawą systemu zasad uczci- 
wości prowadzenia działalności gospodarczej. Zakres ustawy był praktycznie nieograniczony (Zelek, 1999, s. 11). Podmiotowo, nie dotyczyła ona jedynie wolnych zawodów; od strony przedmiotowej zaś ustawa obejmowała m.in. przejmowanie klienteli, podszywanie się pod obcą firmę, zawieranie tzw. umów lawinowych czy też dokonanie czynu sprzecznego z uczciwością kupiecką (Zelek, 1999, s. 13). Ustawa wprowadzała szeroką ochronę cywilnoprawną konkurencji, przewidując możliwość wystąpienia z roszczeniem o zaniechanie, usunięcie przyczyn, odszkodowanie i zadośćuczynienie. W ramach ingerencji prawnokarnej przewidziano zaś stosowanie grzywien, aresztu oraz zatrzymanie towaru na granicy. Wprawdzie po II wojnie światowej formalnie ustawy z 1926 r. nie uchylono, to jednak brak było warunków dla jej stosowania w obrocie (Zelek, 1999, s. 13; Miąsik, 2013, s. 36).

Jak wspomniano, model ochrony konkurencji w okresie międzywojennym (podobnie, jak i obecny) nie ograniczał się wyłącznie do ochrony uczciwości konkurowania. W interesie publicznym zwalczano również kartele. Pierwszą całościową regulacją w tym zakresie była ustawa z 1933 r. o kartelach (Dz. U. nr 31, poz. 270), stanowiąca odpowiedź na zjawisko koncentracji środków produkcji, powstałe m.in. wskutek kryzysu gospodarczego przełomu lat 20. i 30. XX w. (Skoczny, 2009). Ustawa ta wprowadziła obowiązek notyfikacji karteli ministrowi przemysłu i handlu, który prowadził ich rejestr (Ustawa z dnia 28 marca 1933, art. 3). Minister mógł wystąpić do Sądu Kartelowego z wnioskiem o rozwiązanie umowy lub zwolnienie jej uczestników z obowiązku jej wykonywania (od listopada $1935 \mathrm{r}$. minister był już władny sam rozwiązać kartel, zaś jego decyzja mogła być zaskarżona do sądu). Kolejnymi ważnymi dla tworzonego systemu regulacjami były: rozporządzenie ministra przemysłu i handlu z 1933 r. w sprawie rejestru kartelowego (Dz. U. nr 48, poz. 383) oraz ustawa z 1939 r. o porozumieniach kartelowych (Dz. U. nr 63, poz. 418). Wdrożenie ostatniej ustawy zablokował najpierw wybuch II wojny światowej, a następnie po 1945 r. obowiązujący model gospodarczy wykluczający istnienie regulacji antymonopolowych.

W styczniu 1987 r. przyjęto ustawę o przeciwdziałaniu praktykom monopolistycznym $w$ gospodarce narodowej (Dz. U. nr 3, poz. 18 z późn. zm.), mającą na celu ochronę krajowego rynku oraz jego uczestników przed praktykami monopolistycznymi jednostek gospodarczych, ich zrzeszeń oraz związków (Ustawa z dnia 28 stycznia 1987, art. 1), w praktyce o ograniczonym zasięgu. Ustawa wyłączała stosowanie jej postanowień do przedsiębiorstw państwowych podległych wskazanym 
w niej ministrom oraz prezesowi Narodowego Banku Polskiego oraz przewidywała upoważnienie dla Rady Ministrów do modyfikowania jej zakresu podmiotowego i przedmiotowego. Niemniej, powoływała „organ antymonopolowy”, którym był minister finansów oraz działającą przy ministrze Radę do spraw Przeciwdziałania Praktykom Monopolistycznym (z rolą doradczą i opiniującą).

Zmiany ustrojowe po 1989 r. znalazły odzwierciedlenie również w obszarze konkurencji. Jednak ustawa z lutego 1990 r. nastawiona była przede wszystkim na procesy demonopolizacyjne (Miąsik, 2013, s. 41). Ukonstytuowała Urząd Antymonopolowy, przemianowany następnie na Urząd Ochrony Konkurencji i Konsumentów (UOKiK). Kolejnymi jej nowelizacjami poszerzano kompetencje organu antymonopolowego, m.in. podporządkowując prezesowi UOKiK Inspekcję Handlową, zobowiązując prezesa do opracowywania rządowych projektów polityki konsumenckiej oraz powierzając mu zadania „,z zakresu ochrony konsumentów poza instytucjami prawa antymonopolowego" (Miąsik, 2013, s. 45).

Ważnym impulsem dla rozwoju systemu prokonkurencyjnego stało się podpisanie przez Rzeczpospolitą Polską, w dniu 16 grudnia 1991 r., Układu Europejskiego ustanawiającego stowarzyszenie między Wspólnotami Europejskimi i ich państwami członkowskimi z jednej strony a Rzeczpospolitą Polską z drugiej strony (tekst stanowi załącznik do Dz. U. z 1994 r., nr 11, poz. 38). Artykuł 63 dokumentu przewidywał - dla oceny praktyk wpływających negatywnie na stosunki handlowe - odesłanie do kryteriów określonych w art. 85, 86 i 92 wówczas obowiązującego traktatu ustanawiającego Europejską Wspólnotę Gospodarczą, co „stwarzało nowy wymiar i standard zasad ochrony konkurencji” (Borkowski, 2011, s. 3). Przemiany ustrojowo-prawne, okrzepnięcie gospodarki wolnorynkowej oraz dążenia do zbliżenia ze strukturami wspólnotowymi rodziły nowe wyzwania w sferze ochrony konkurencji i konsumentów (Skoczny, 2009). Kolejna ustawa została uchwalona 15 grudnia 2000 r. (j.t. Dz. U. z 2005 r., nr 244, poz. 2080). Wzorowana na prawie wspólnotowym, dokonywała zmian w sferze terminologicznej - pojęcie „praktyk monopolistycznych” zastąpiono „praktykami ograniczającymi konkurencję”, zaliczając do nich porozumienia ograniczające konkurencję oraz praktyki polegające na nadużywaniu pozycji dominującej. Ponadto „po raz pierwszy w polskim ustawodawstwie antymonopolowym pojawiła się - w odniesieniu do porozumień ograniczających konkurencję - zasada de minimis oraz możliwość tzw. wyłączenia grupowego” (Skoczny, 2009). W porównaniu z wcześniejszymi regulacjami „poszerzono 
regulację procesową" (Borkowski, 2011, s. 4), a prezes UOKiK zyskał możliwość prowadzenia postępowania wyjaśniającego w celu ustalenia, czy sprawa ma charakter antymonopolowy. Ustawa była kilkakrotnie nowelizowana, zanim ostatecznie uchylono ją po przyjęciu w dniu 16 lutego 2007 r. kolejnej regulacji, której potrzeba wprowadzenia była jednak mocno kontestowana w literaturze przedmiotu (np. Król-Bogomilska, 2009, s. 4 i przywołana tam literatura). Analogicznie do wcześniejszych przepisów, obowiązująca ustawa zawiera dwa zasadnicze, powiązane ze sobą obszary regulacji: antymonopolową i konsumencką (Skoczny, 2014, pkt 13).

\section{Rodzaje modeli publicznoprawnej ochrony konkurencji}

Współczesne modele instytucjonalne ochrony konkurencji można sprowadzić do dwóch podstawowych typów rozwiązań: sądowego oraz administracyjnego (Błachucki, 2012, s. 52; Moszyńska, 2013, s. 251-252). Jako trzeci model wskazuje się niekiedy także model mieszany (sądowo-administracyjny) (Skoczny, 2011, s. 81). Zasadniczo główna linia podziału pomiędzy wskazanymi systemami dotyczy tego, jakiego rodzaju podmiotom (sądowym lub administracyjnym) przyznana została kompetencja do orzekania w sprawach dotyczących konkurencji. Jako przykład modelu sądowego wskazuje się na Austrię, w której w sprawach ochrony konkurencji orzeka wyłącznie specjalny Sąd Kartelowy (Kartellgericht) (Skoczny, 2011, s. 81; Warzybok, 2009, s. 43-47). Rola organów administracji sprowadza się do czynności kontrolnych, dochodzeniowych, a w przypadku stwierdzonego naruszenia do inicjowania właściwego postępowania (Skoczny, 2011, s. 81; Moszyńska, 2013, s. 251; Warzybok, 2009, s. 43).

Model administracyjny z kolei charakteryzuje decydująca rola organów administracji publicznej, tak co do inicjowania i prowadzenia postępowania, jak i w zakresie orzeczniczym. W ramach modelu administracyjnego można wyróżnić submodel dualistyczny lub monistyczny. W ramach zaś tego ostatniego, z uwagi na sposób orzekania o naruszeniu materialnych reguł konkurencji (Skoczny, 2011, s. 84 i nast.), wyodrębnia się: model monistyczny z kolegialnym organem orzeczniczym w ramach urzędu ochrony konkurencji, model monistyczno-kolegialny, model monistyczno-monokratyczny z elementami odrębności orzekania, model monistyczny z organem ochrony konkurencji dysponującym kolektywnym zarządem oraz czysty model monistyczno-monokratyczny. W modelu dualistycznym funkcje dochodze- 
niowa i orzecznicza pełnione są przez dwa odrębne organy administracji (jeden organ prowadzi postępowanie, a inny orzeka w sprawie). W modelu tym organ orzeczniczy, choć formalnie nie jest sądem, „ma jednak charakter quasi-sądowy” (model taki istnieje np. w Luksemburgu, Argentynie, Chile i na Malcie) (Skoczny, 2011, s. 83). Model administracyjny monistyczny (niezależnie od dalszych wariantów) przewiduje jeden organ administracyjny, który prowadzi postępowanie i wydaje decyzje administracyjne, zaś sąd rozpatruje odwołania od tych właśnie decyzji. Model monistyczny wydaje się być dominujący (Skoczny, 2011, s. 82), zaś w jego ramach najczęściej spotyka się model monistyczno-kolegialny lub monistyczno-monokratyczny (w przypadku pierwszego organ administracyjny właściwy w sprawach ochrony konkurencji ma charakter kolegialny, w drugim zaś jest jednoosobowy).

O modelu mieszanym (obecnym m.in. w Wielkiej Brytanii, Irlandii, Finlandii) można mówić, gdy kompetencje w zakresie orzekania w sprawach konkurencji współdzielone są przez organy administracji i sądownicze (Skoczny, 2011, s. 89). Istnieje zatem duża różnorodność modeli instytucjonalnych w zakresie ochrony konkurencji, która jest podyktowana nie tylko potrzebą poszukiwania najbardziej efektywnych rozwiązań, ale także uwarunkowaniami kulturowymi i prawnymi. W literaturze zauważa się, że model monokratyczny najczęściej spotyka się w państwach o jeszcze nieugruntowanym systemie ochrony konkurencji (Warzybok, 2009, s. 54).

\section{Model ochrony obowiązujący w Polsce}

Moszyńska (2011, s. 251) wskazuje, że pierwszy model w międzywojennej Polsce był modelem sądowym, zauważa jednak, że nie funkcjonował on w czystej postaci, gdyż Sąd Kartelowy był ograniczony wnioskiem ministra przemysłu i handlu, zaś od 1935 r. rozpatrywał wyłącznie odwołania od decyzji ministra w sprawach kartelowych. Wydaje się, iż od początku tworzenia systemu publicznej ochrony konkurencji polskiemu ustawodawcy bliżej było do modelu administracyjnego niż sądowego, co nie powinno dziwić, skoro ochrona ta miała przybrać formę interwencji administracyjnej. Obowiązujący obecnie model kwalifikuje się jako administracyjny, w wariancie monistyczno-monokratycznym (Skoczny, 2011, s. 89). 
Zarówno formuła prawna organu, jak i zakres jego kompetencji podlegały zmianom dyktowanym nie tylko potrzebą dostosowania standardów krajowych do wymagań wspólnotowych, ale także chęcią wzmocnienia jego skuteczności.

Jak już wskazano, pierwszym organem antymonopolowym był na mocy ustawy z 1987 r. minister finansów, do którego należało czuwanie nad przestrzeganiem przepisów o przeciwdziałaniu praktykom monopolistycznym w gospodarce narodowej, w szczególności poprzez wydawanie decyzji i nakładanie kar pieniężnych. Następnie ustawą z 1990 r. powołano do życia Urząd Antymonopolowy, jako organ kolegialny, który z czasem przekształcono w organ monokratyczny, tj. w Prezesa Urzędu Antymonopolowego, a obecnie Prezesa Urzędu Ochrony Konkurencji i Konsumentów. Zgodnie z obowiązującą ustawą Prezes UOKiK jest centralnym organem administracji rządowej w sprawach ochrony konkurencji i konsumentów (Ustawa z 16 lutego 2007, art. 29, ust. 1). Z racji bezpośredniego podporządkowania Prezesowi Rady Ministrów organ antymonopolowy należy do organów nazywanych samodzielnymi (Borkowski, 2011, s. 4), choć z uwagi na sposób wyboru na to stanowisko, brak kadencyjności oraz ustawowych gwarancji nieodwoływalności w literaturze jego niezależność jest kontestowana (Błachucki, s. 85; Moszyńska, 2013, s. 255).

Ustawa o działach administracji rzadowej (j.t. Dz. U z 2015 r., poz. 812) nie zalicza ochrony konkurencji i konsumentów do żadnego z wymienionych w niej działów. Zadaniem systemu ochrony antymonopolowej są bowiem zadania realizowane w układzie horyzontalnym (UOKiK, 2015, s. 11 i nast.), w czterech zasadniczych obszarach: zwalczania antykonkurencyjnych porozumień pomiędzy przedsiębiorcami, zwalczania praktyk przejawiających się w nadużywaniu pozycji dominującej, kontroli koncentracji oraz monitorowania pomocy publicznej. W sprawach określonych ustawą prezes wydaje decyzje administracyjne, które następnie mogą zostać zweryfikowane przez sąd (w ramach procedury cywilnej). $Z$ tego też powodu postępowanie w sprawach ochrony konkurencji zaliczane jest do tzw. postępowań hybrydowych (Kabacińska, 2012, s. 6; Niziołek, Famirska, 2008, s. 34 i nast.).

W przyjętym w Polsce modelu ochrony istotną rolę odgrywa również sąd antymonopolowy. W międzywojniu tego typu sąd (jednoinstancyjny Sąd Kartelowy) miał charakter ławniczy i wzorowany był na rozwiązaniach niemieckich (Błachucki, 2011, s. 7). Sąd Kartelowy orzekał jako sąd pierwszej instancji lub odwoławczy, zaś jego orzeczenia nie podlegały zaskarżeniu. 
W Polsce Ludowej sądownictwo antymonopolowe nie funkcjonowało aż do 1987 r., kiedy to sądem właściwym w sprawach antymonopolowych stał się Naczelny Sąd Administracyjny. Jego rola była jednak dość ograniczona. Dopiero pod koniec lat 80 . XX w. powołano wyspecjalizowany Sąd Antymonopolowy (od 2002 r. Sąd Okręgowy w Warszawie - Sąd Ochrony Konkurencji i Konsumentów), którego orzeczenia początkowo były niezaskarżalne. Trybunał Konstytucyjny rozwiązanie to uznał za niezgodne z konstytucją (Wyrok Trybunału Konstytucyjnego z 12 czerwca 2002 r., OTK-A $2002 \mathrm{nr}$ 4, poz. 42) i od 2004 roku postępowanie sądowe w sprawach antymonopolowych jest już postępowaniem dwuinstancyjnym. Zgodnie z art. $479^{28}$ i nast. k.p.c. SOKiK rozpatruje środki zaskarżenia wniesione od decyzji i postanowień wydanych w postępowaniach administracyjnych, w tym również przez organy regulacyjne (z zakresu regulacji energetyki, telekomunikacji i poczty oraz transportu kolejowego).

\section{Podsumowanie}

Polityka państwa bez wątpienia wpływa na procesy konkurencji na rynku. Po 1989 roku zyskała ona nowy kierunek, czego efektem było wprowadzenie i udoskonalanie obecnych rozwiązań także w zakresie modelu ustrojowego. Można by się zastanawiać, czy przyjęcie innego modelu ochrony konkurencji (np. sądowego) pozwoliłoby na bardziej efektywną ochronę rynku i jego uczestników. Wydaje się, że model sądowy, z uwagi na pozycję ustrojową organów sądowniczych, nie pozwoliłby na realizację polityki prokonkurencyjnej w takim wymiarze jak obecnie.

Uzasadnieniem ingerencji państwa jest nadal ochrona gospodarki przed degeneracją, zapewnienie swobody działalności i równych praw wszystkim uczestnikom rynku. Niezależność organu antymonopolowego od bieżącej polityki rządu, choć postulowana, nie wydaje się być możliwa, zwłaszcza gdy coraz trudniej pogodzić idee państwa prawnego i socjalnego z warunkami wolnorynkowymi.

\section{Literatura}

Bernatt, M., Jurkowska-Gomułka, A., Skoczny T. (2014). Podstawy i zakres publicznoprawnej ochrony konkurencji. W: M. Kępiński (red.), System Prawa Prywatnego. 
Tom 15. Prawo konkurencji, (s. 4 i nast.). Warszawa: C.H. Beck/Instytut Nauk Prawnych PAN.

Błachucki, M. (2012). System postepowania antymonopolowego w sprawach kontroli koncentracji przedsiębiorców, Warszawa: wyd. Urzędu Ochrony Konkurencji i Konsumentów.

Borkowski, J. (2011). Postępowanie przez Prezesem Urzędu Ochrony Konkurencji i Konsumentów. Studia Prawa Prywatnego, 3-4, 4-38.

Gronowski, S., Wojtaszek-Mik, E. (1998). Ustawa antymonopolowa. Orzecznictwo. Piśmiennictwo. Przepisy. Warszawa.

Kabacińska, N. (2012). Prawo ochrony konkurencji, dodatek specjalny do Edukacji Prawniczej, 11, 112-118.

Kosikowski, C. (2010). Publiczne prawo gospodarcze Polski i Unii Europejskiej. Warszawa, wyd. 4.

Krasnodębska-Tomkiel, M. (2015). Konwergencja systemów ochrony konkurencji w Unii Europejskiej w zakresie przeciwdziałania praktykom ograniczającym konkurencję. Europejski Przegląd Sądowy, 7, 20-27.

Król-Bogomilska, M. (2009). Kierunki najnowszych zmian polskiego prawa antymonopolowego. Europejski Przegląd Sądowy, 6, 4-12.

Lewandowski, M. (2012). Sankcja nieważności w ustawie antymonopolowej-problematyka kompetencji organów w przedmiocie ustalania naruszenia zakazów antymonopolowych. Przegląd Prawa Handlowego, 2, 32-39.

Miąsik, D. (2013). Rozwój polskiego prawa konkurencji i prawa antymonopolowego. Studia Prawa Prywatnego, 1, 35-52.

Moszyńska, A. (2013). Instytucjonalne ramy ochrony konkurencji w Polsce - historia i współczesność. Ekonomia i Prawo, 2, 245-259. DOI: http://dx.doi.org/10.12775/ EiP.2013.019.

Niziołek, M., Famirska, S. (2008). Procedura hybrydowa w sprawach ochrony konkurencji a ostateczność i wykonalność decyzji Prezesa UOKiK. Przegląd Prawa Handlowego, 4, 34-39.

Podrecki, P. (1994). Stosunek ustawy o zwalczaniu nieuczciwej konkurencji do ustawy o przeciwdziałaniu praktykom monopolistycznym. Przeglad Prawa Handlowego, 12, 20-28.

Powałowski, A., Koroluk, S., Mering, L. (2004). Prawo ochrony konkurencji, Warszawa.

Säcker, F.J. (2010). Prawo ochrony konkurencji oraz prawo zwalczania nieuczciwej konkurencji i ich stosunek do prawa cywilnego. Prace z Prawa Własności Intelektualnej, 110, 6 i nast. 
Sieradzka, M. (2010). Dochodzenie roszczeń za naruszenie unijnych i krajowych reguł konkurencji. Przegląd Prawa Handlowego, 12, 47-55.

Sieradzka, M. (2015). Zmowy przetargowe w świetle prawa zamówień publicznych oraz prawa konkurencji. Warszawa: C.H. Beck.

Skoczny, T. (red.). (2009). Ustawa o ochronie konkurencji i konsumentów. Komentarz. Komentarz do art. 1. Warszawa: SIP Legalis.

Skoczny, T. (2010). Polskie prawo kontroli koncentracji - ewolucja, model, wybrane problemy. Europejski Przegląd Sądowy, 5, 15-21.

Skoczny, T. (2011). Instytucjonalne modele wdrażania reguł konkurencji na świecie - wnioski dla Polski. Ruch Prawniczy Ekonomiczny i Społeczny, 2, 77-98.

UOKiK (2016). Polityka ochrony konkurencji i konsumentów. Warszawa: Urząd Ochrony Konkurencji i Konsumentów. Pobrane z: https://uokik.gov.pl/kompetencje_prezesa uokik.php (21.04.2016).

Ustawa z dnia 13 lipca 1939 r. o porozumieniach kartelowych (Dz. U. nr 63, poz. 418).

Ustawa z dnia 15 grudnia 2000 r. o ochronie konkurencji i konsumentów (j.t. Dz. U. z 2005 r., nr 244, poz. 2080).

Ustawa z dnia 16 kwietnia 1993 r. o zwalczaniu nieuczciwej konkurencji (j.t. Dz. U. z 2003 r., nr 153, poz.1503).

Ustawa z dnia 16 lutego 2007 r. o ochronie konkurencji i konsumentów (j.t. Dz. U z 2015 r., poz. 184).

Ustawa z dnia 28 stycznia 1987 r. o przeciwdziałaniu praktykom monopolistycznym w gospodarce narodowej (Dz. U. nr 3, poz. 18 z późn. zm.).

Ustawa z dnia 2 sierpnia 1926 r. o zwalczaniu nieuczciwej konkurencji (j.t. Dz. U. z 1930 r., nr 56, poz. 467).

Ustawa z dnia 24 lutego 1990 r. o przeciwdziałaniu praktykom monopolistycznym i ochronie interesów konsumentów (j.t. Dz. U z 1999 r. nr 52, poz. 547).

Ustawa z dnia 28 marca 1933 r. o kartelach (Dz. U. nr 31, poz. 270).

Ustawa z dnia 4 września 1997 r. o działach administracji rządowej (j.t. Dz. U. z 2016 r. poz. 543).

Warzybok, A. (2009). Instytucjonalne modele ochrony konkurencji w wybranych państwach europejskich na przykładzie Austrii, Belgii oraz Bułgarii, ZNEZ WSiZ nr 2, 36-57.

Wyrok Trybunału Konstytucyjnego z 12 czerwca 2002 r., OTK-A 2002 nr 4, poz. 42.

Zelek, A. (1999). Rewizja współczesnej polityki antymonopolowej - przegląd poglądów i systemów. Polityka Gospodarcza, 2, 5-24. 


\title{
PUBLIC-LAW COMPETITION MODEL IN POLAND
}

\begin{abstract}
The aim of this article is presentation of the solutions adopted in Poland, in the area of competition protection, also from historical perspective. As based on the analysis of literature and source documents this article presents the evolution of the public model of that protection. It describes, by using descriptive method, the current position of this specialized body, as well as briefly some of his powers.
\end{abstract}

Translated by Magdalena Dąbrowska

Keywords: model of competition protection, of public law protection, the competition authority

Kody JEL: K2, K21 